\title{
Review: Livestock production increasingly influences wildlife across the globe
}

\author{
I. J. Gordon ${ }^{1,2,3 \dagger}$ \\ ${ }^{1}$ Division of Tropical Environments \& Societies, James Cook University, 1 James Cook Drive, Townsville, QLD 4811, Australia; ${ }^{2}$ James Hutton Institute, Craigiebuckler, \\ Aberdeen AB15 8QH, UK; ${ }^{3}$ Fenner School of Environment \& Society, Australian National University, Canberra, ACT 2601, Australia
}

(Received 16 January 2018; Accepted 3 May 2018; First published online 24 August 2018)

With the growing human population, and their improving wealth, it is predicted that there will be significant increases in demand for livestock products (mainly meat and milk). Recent years have demonstrated that the growth in livestock production has generally had significant impacts on wildlife worldwide; and these are, usually, negative. Here I review the interactions between livestock and wildlife and assess the mechanisms through which these interactions occur. The review is framed within the context of the socio-ecological system whereby people are as much a part of the interaction between livestock and wildlife as the animal species themselves. I highlight areas of interaction that are mediated through effects on the forage supply (vegetation) - neutral, positive and negative - however, the review broadly analyses the impacts of livestock production activities. The evidence suggests that it is not the interaction between the species themselves but the ancillary activities associated with livestock production (e.g. land use change, removal of predators, provision of water points) that are the major factors affecting the outcome for wildlife. So in future, there are two key issues that need to be addressed - first, we need to intensify livestock production in areas of 'intensive' livestock production in order to reduce the pressure for land use change to meet the demand for meat (land sparing). And second, if wildlife is to survive in areas where livestock production dominates, it will have to be the people part of the socioecological system that sees the benefits of having wildlife co-exist with livestock on farming lands (land sharing and win-win).

Keywords: livestock, wildlife, wildlife-livestock interactions, facilitation, competition

\section{Implications}

The global human population has dramatically increased in the past 50 years and will continue to do so for at least the next 30 years. Alongside improvements in income, this is leading to significant increases in the demand for livestock products. History shows that livestock production negatively impacts wildlife, some of this is direct through competition for resources, but much of it is associated with land use change and livestock management practices. This will continue unless we create the circumstances in which wildlife and livestock can coexist, through farmers benefiting from wildlife on their land. The imperative lies, however, in finding ways to improve the efficiency of livestock production so that land is not converted to produce livestock products and remains for wildlife.

\section{Introduction}

The human population of the globe currently sits at around 7.5 Billion and is likely to increase to 9 to 11 Billion in the

\footnotetext{
${ }^{\dagger}$ E-mail iain.gordon@jcu.edu.au
}

next 30 years (United Nations, 2017). Much of this increase has happened in the developing world, and Asia and Africa are likely to be the major contributors to population growth by 2050 (United Nations, 2017). The growing population in the developing world is also getting richer, with Gross Domestic Product increasing in lower- and middle-income countries by $180 \%$ in the past 10 years (World Bank, 2017). As well as moving people out of poverty, this increase in wealth is associated with changing dietary habits, as people shift from a predominately grain-based diet to one that includes increasing amounts of meat, initially poultry but then pigs, and red meat from goats, sheep and cattle (Delgado et al., 1999; Alexandratos and Bruinsma, 2012). Although grain is increasingly used to provide the feed required for these livestock, land use change is also associated with increased livestock production. For example, it is projected that the land area under permanent pasture in lower- and middle-income countries (particularly in South America and sub-Saharan Africa) will expand by $~ 320$ Mha by 2030 (from 2010; Wirsenius et al., 2010), with increases in livestock numbers of between $40 \%$ and $50 \%$ for buffalo, Bubalus bubalis, and cattle, Bos taurus, and $30 \%$ to $45 \%$ 
for sheep, Ovis aries, and goats, Capra aegagrus hircus (Bruinsma, 2003).

Livestock production now occupies over a quarter of the land surface area of the globe (Robinson et al., 2014). Obviously, conversion of land to support livestock production occurs at the expense of land that is currently occupied by forests and other native vegetation (Foley et al., 2005). This change in land use puts pressure on wildlife populations, through either direct effects (e.g. persecution) or indirect effects (e.g. land clearing, fencing). These effects (impacts) are likely to increase as the demand, for particularly, red meat increases. The extent to which they herald the decline in wildlife populations depends upon the nature of the interactions; as discussed below.

Livestock production, and wildlife species are part of a socio-ecological system (Biggs et al., 2015), meaning that humans play a major role in determining the outcome of interactions between components of the system. Thus, a focus on the interactions between livestock and wildlife can miss the perceptions and behaviours of, for example, farmers or wildlife managers, who will determine management actions that impact on those interactions. As researchers, we cannot, therefore, approach the issue of the future of wildlife in livestock production dominated landscapes through reductionism-based research; we have to see it within the context of the whole socio-ecological system.

In this review, I will first describe these livestock-wildlife interactions, provide evidence for their effects on wildlife and vice versa, provide a narrative for the extent to which future management interventions can ameliorate these interactions and highlight key areas for future research. I will focus on the interactions between livestock and wildlife that are mediated through nutrition, but to understand the story for the 21st Century, I will draw more broadly on the complexity of interactions within the socio-ecological system within which livestock-wildlife interactions occur. The future of many of our wildlife species is intimately connected to the future of livestock production; I will chart a future that is positive in a world where negative stories dominate.

\section{Definitions}

Before we get into the meat of the review, it is important to clarify the boundaries within which the narrative for the discussion unfolds. First, it is important to define what I mean by livestock and wildlife. In general terms, livestock means any species of animal that has been domesticated and which are kept in an agricultural context. This can be anything from chickens, Gallus gallus domesticus, and guinea pigs, Cavia porcellus, to sheep and cattle. In this context, I will confine myself to domesticated large mammals that use herbage as their primary feed, for example camels, Camelus spp., horses, Equus caballus, goats, sheep and cattle. Second, wildlife is a catch-all term for species of any native, non-domesticated organism, including fungi, plants and animals. This definition is clearly too broad for the purposes of this review and, so, I will confine the discussion to native large mammal species that feed on vegetation, primarily ungulates and macropods.

Ecology is the study of organisms and the way that they interact with the world around them, the ecosystems in which they live. The ecosystems include other organisms of their own species and different species. The organisms can be food, they can be predators, they may be competitors or facilitators, or they may be, occasionally, neutral in terms of their effects on a particular organism or species. Food and predation clearly are direct interactions between organisms, but competition and facilitation generally occur through direct or indirect effects generally mediated, in the case of this review, by changes in vegetation abundance, composition, structure and quality.

Agricultural systems come in all shapes and sizes, from small holders who cut herbage to feed to individual animals in pens, through intensive systems, where the native vegetation has been converted to agronomic species, and feed and water is supplied, either all year or at certain times of forage and water constraints, to extensive systems where inputs are low, livestock roam over large areas feeding upon native vegetation and, to a large extent, fend for themselves. Agricultural systems also have other components that can affect wildlife, for example, humans tend their stock and fences constrain the movement of wildlife onto the farm.

The agricultural practice of livestock production is associated with a number of changes in the landscape, many of which can interact with wildlife. By their very nature these effects are complex and depend upon the circumstance, and the form, that livestock production takes. In the following three sections I will look specifically at the effects on the forage supply for wildlife and vice versa; I will then follow with a broader discussion of the effect of management interventions associated with livestock production on wildlife.

\section{Interactions between livestock and wildlife}

\section{Neutral interactions}

In a number of cases, where livestock and wildlife co-exist, research has concluded that there is little impact of livestock on wildlife and vice versa mediated through forage supply (i.e. neutral; Figure 1; see also Schieltz and Rubenstein, 2016). For example, a recent comprehensive analysis by Schieltz and Rubenstein (2016) found that of the 155 studies analyses over $20 \%$ showed no effect of livestock on wildlife. This may be because livestock are at low densities in these studies and, therefore, do not affect the resources needed by the wildlife species, or there is niche partitioning between the livestock and wildlife species in question. Effective tests of whether the nutritional interactions between livestock and wildlife are really neutral require experiments in which the metabolic/weight densities of the livestock and wildlife are equal in situations where they occur individually or together (e.g. see Hester et al., 1999). These have rarely been carried out (see below).

Although, neutral interactions are often recorded in the studies analysed by Schieltz and Rubenstein (2016), it is 

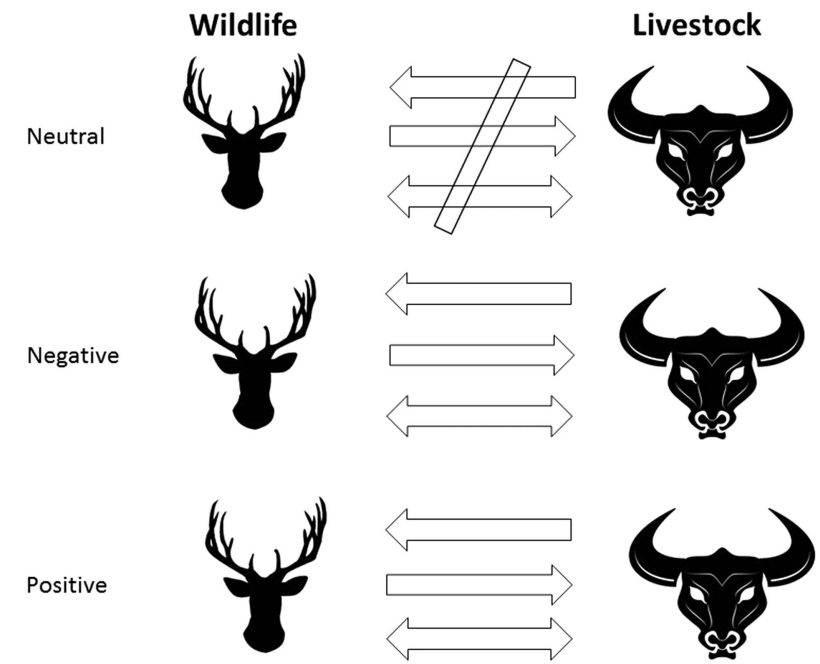

Figure 1 Types of interactions that can happen between wildlife and livestock. Note the direction of the arrow shows the direction of the interaction (double arrow means two way). Wildlife Image: http://www. pngmart.com/image/19342; Livestock image: https://www.vecteezy.com/ birds-animals/22374-bull-head-vector.

highly unlikely that there are no direct or indirect positive or negative effects of wildlife on livestock and vice versa (probably the latter). This is because of the scale of the analysis is usually small, plot, paddock, farm. The true interactions within the socio-ecological system happen at a much larger scale. Take, for example, the fact that agriculture tends to displace wildlife from the most productive parts of the landscape (Foley et al., 2005); although there is evidence from Europe that agricultural desertification has resulted in expansion of wildlife populations (Gordon 2009; Acevedo et al., 2011; a clear indication that livestock production does displace wildlife). With the expansion of livestock production, wildlife either moves to or is left in the marginal areas, where individual and population performance of nonadapted species is likely to be low relative to the areas of better soils/climate now occupied by livestock production (Newby, 2014). This can also lead to increased competition between wildlife species that have moved into marginal areas and those that are more adapted to these areas. Even protected areas that are set aside for wildlife tend to be in marginal areas of a country (e.g. Izquierdo and Grau, 2009). As such, the interaction between livestock production, as an overall activity, and wildlife, is unlikely to be neutral except in the short time scales of local observation.

\section{Negative interactions}

For direct (interference) competition to take place between livestock and wildlife they have to share a common set of resources, in space and time, that are limiting and the effects are evident through the growth, reproduction and population dynamics of one or both species (negative; Figure 1 and Wiens, 1989). Indirect (exploitative) competition can occur where there is a spatial and temporal separation of the use of common resources that become limiting to one, or both species, in a certain place, at some time/s of the year. Again, for a concrete evidence of direct competition, there should be negative impacts on growth, reproduction and population dynamics of one or both species. Below I will highlight two areas of competition, space and forage.

Space. Livestock production is generally seen as having a negative impact on wildlife (e.g. Western, 1989; du Toit and Cumming, 1999). Again, in the analysis by Schieltz and Rubenstein (2016) over $55 \%$ of studies showed negative effects of livestock on wildlife. Many of these effects are caused by direct interference competition whereby wildlife species left an area when livestock, particularly cattle, were present (e.g. Stewart et al., 2002). In Stewart et al. (2002) the cattle were free ranging and humans were not present for much of the time that cattle used the range. Still elk, Cervus elaphus nelsoni, and mule deer, Odocoileus hemionus hemionus, avoided areas used by cattle within a 6-h window of analysis (short-term associative competition) and the 7-day window of analysis (longer term competition); whereas elk and mule deer avoided each other in the 6-hour window but not the 7-day window. This suggests it is something about cattle that the deer species were avoiding, and that both direct and indirect competition is taking place. The direct effect appears to be common across different continents and taxa (e.g. Schroeder et al., 2013; Khadka and James, 2016) but the effect is confounded in many cases by the presence of humans (Western et al., 2009). It is not clear why wildlife avoid livestock even when humans are not present.

Forage. If we look at negative interactions that occur through the indirect competition for food resources, there is even less broad evidence. Theoretically, we would expect that species that occupy similar niches to livestock (grazers for cattle and sheep, and browsers for goats) would be most affected by the presence of livestock, with less effect on species that occupy different niches (Gordon and Illius, 1989). Merrill et al. (1957) did indeed find that white-tailed deer, Odocoileus virginianus, predominately a browser, responded more negatively to the presence of goats than they did to cattle or sheep; also guanaco, Lama guanicoe, a specialist mixed feeder, avoided areas used by sheep and goats more than they did those used by cattle (Schroeder et al., 2013).

We would also expect that smaller species would be able to outcompete larger species for shared resources when herbage is in short supply (Illius and Gordon, 1987). Du Toit and Olff (2014) conclude that indirect competitive dominance by smaller species of herbivores is the predominant mechanism that structures ungulate assemblages when shared resources become limiting. One would, therefore, expect sheep and goats to outcompete larger wildlife species that share their niche and that cattle would be more likely to suffer competition from smaller grazing/generalist wildlife species. There is not sufficient evidence to be able to test this hypothesis, however, the general conclusion is that cattle have a negative impact on many species (Schieltz and Rubenstein (2016), even those smaller than themselves and occupying different niches. One possible explanation for this 
conclusion is that livestock biomass, predominately cattle, is generally high relative to expectations for wildlife herbivores because of the inputs from livestock management systems (Hempson et al., 2015). This points to the fact that livestock production, as an activity, drives many of the interactions between livestock and wildlife (see below). In a broadranging survey of African systems, Fynn et al. (2016) provide a set of criteria upon which competition would be expected to occur between livestock and wildlife. Most of these are predicted to result from competition for limited resources during the dry season, or in years with lower than average rainfall.

One other area that indicates competition for food between livestock and wildlife is niche or dietary breadth. A number of studies have found that there is a narrowing of the niche/diet breadth of wildlife in the presence of livestock suggesting that livestock are outcompeting wildlife in certain parts of the shared niche/forage resources. For example, in a recent study Traba et al. (2017) found a narrowing of the diet in guanaco in the presence of domestic livestock (particularly sheep which occupy a similar niche). This suggests, at least an alteration, and more likely, a reduction in the nutrition of guanaco diets in the presence of domestic species. One would expect this effect to be less prevalent where there is greater niche dissimilarity between livestock and wildlife species (Fritz et al., 1996; Herfindal et al., 2017).

The extent to which livestock interactions with their environment will have a negative effect on wild life is often a matter of degree. In the majority of situations, involving livestock production, ecological interactions are overridden by the inputs that are associated with the production system itself (see below). These allow livestock to exist at significantly higher densities than if the inputs were not provided or the ecosystems are occupied by wildlife alone (Hempson et al., 2015), leading to excessive grazing pressure being exerted on the vegetation (du Toit et al., 2017). Where this occurs over a long period, there are reductions in vegetation abundance, complexity, diversity and cover, all of which reduce the forage available to wildlife species (Boone et al., 2005). These changes in the food resource will have impacts, not only on wildlife species that occupy similar niches to those of livestock but also those which are affected by, for example, changes in vegetation composition (Mishra et al., 2004; Ogutu et al., 2010). A striking example occurs in semi-arid regions of the world where management practices of supply of artificial water have resulted in concentrated livestock around artificial water points. The congregation of livestock around water points can result in a grazing gradient (heavy defoliation gradient near water points; piosphere) (Boone et al., 2005) that has a negative impact on wildlife use of the landscape. Wildlife tend to be found further away from water points (possibly because they are also less waterdependent than, e.g. cattle) (de Leeuw et al., 2001); although browsing and grazing species may differ in their responses, with grazing species tending to be more closely associated with artificial water points than browsing species (Smit et al., 2007).

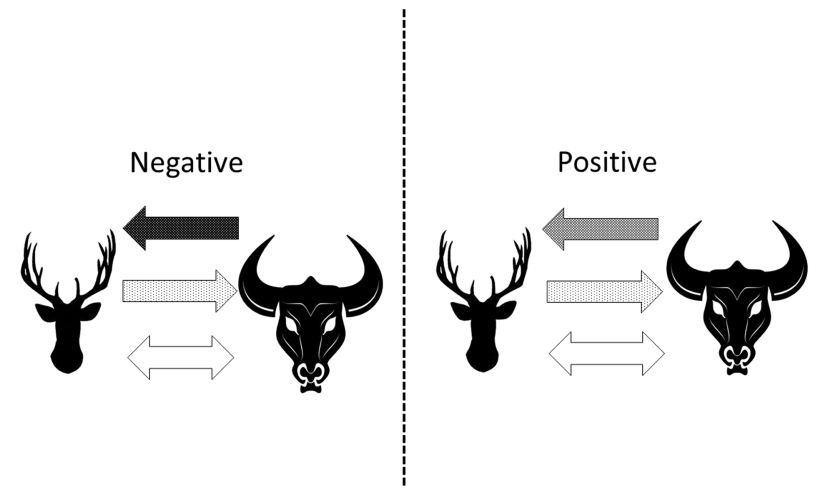

Figure 2 (a) Negative interactions that can happen between wildlife and livestock. (b) Positive interactions that can happen between wildlife and livestock. Note the direction of the arrow shows the direction of the interaction (double arrow means two way); the greyscale gives a qualitative assessment of the weight of evidence from the literature (see also Schieltz and Rubenstein, 2016). Wildlife Image: http://www.pngmart. com/image/19342; Livestock image: https://www.vecteezy.com/birdsanimals/22374-bull-head-vector.

Very few studies have found wildlife to have negative effects on livestock; however, Odadi et al. (2011) did find that wildlife reduced the food resource for cattle during the dry season when resource constraints were at their most severe, leading to a reduction in cattle performance. In Australia competition for forage by native grazers, that is, red kangaroos Macropus rufus and grey kangaroos M. giganteus and common wallaroos M. robustus, (Edwards et al., 1996) is estimated to cost the livestock industry $\sim$ A $\$ 15$ million per annum (McLeod, 2004). More than five million kangaroos and wallaroos are culled per year to reduce this conflict, despite the fact that it is not known the extent to which this actually reduces competition (Pople \& McLeod, 2000).

Overall, the literature suggests that, where negative interactions occur, there are stronger negative impacts of livestock on wildlife than vice-a-versa and little evidence of two-way interactions (Figure 2a).

\section{Positive interactions}

In ecology, positive interactions between species can be facultative (commensal) or synergistic (mutualistic) (positive; Figure 1). Facultative interactions are unidirectional, where the ecology of one species benefits another species. For example, egrets, Bubulcus ibis, follow cattle in pastures, feeding off the insects that are disturbed by the cattle's foraging behaviour; the cattle gain no advantage from the egrets. In synergistic interactions, both species benefit from the presence of each other. For example, lichens are a composite made up of algae or bacteria living with a fungus; the fungus benefits from the carbohydrates produced by the algae or bacteria which themselves benefit from the protection afforded by the fungus. As with negative interactions positive interactions can be direct or indirect.

Space. I can find no evidence for direct positive interactions, for example, where, say, livestock directly reduce the likelihood of 
predation on wildlife and vice versa which allows the utilisation of preferred resources where predation rate is normally high. However, domestic llamas, Lama glama, have been used to reduce predation by coyotes, Canis latrans, on domestic sheep (Franklin et al., 1994). It would be interesting to see whether guanacos or other wildlife play the same role.

Forage. At lower levels of livestock density, than those that cause extensive ecosystem degradation (see above), livestock grazing can increase the structural heterogeneity, change species composition, reduce vegetation component that impedes intake and improves vegetation quality (review by Fynn et al., 2016). These changes can, in turn, benefit wildlife populations. The study of Gordon (1988) was seminal in showing that the use of a high biomass, but poor quality, vegetation community during the Scottish winter, stimulated early vegetation regrowth in the spring, and, this regrowth, was used by red deer, Cervus elephus, in preference to other areas of that vegetation community. Through an analysis of areas of the Isle of Rum, which were used by cattle, and those that were not, Gordon (1988) showed that red deer performance was higher where cattle were present, suggesting that cattle grazing facilitated the foraging of red deer leading to improved population performance. Since that study there have been numerous other examples published of the effect of facilitation by livestock, particularly cattle, to wildlife. Again, in the analysis by Schieltz and Rubenstein (2016) over 20\% of studies showed positive effects between livestock and wildlife. For example, across large areas of the USA, livestock grazing is used as a means of improving the habitat for elk (Krausman et al., 2009). The emphasis has been on using rotational grazing to enhance the quantity and quality of forage for elk leading to the improved elk population performance (Frisina and Keigley, 2004). In Australia, it is thought that cattle grazing increases the 'green pick', that is regrowth, which is utilised by kangaroo species, Macropus spp, and has led to significant increases in kangaroo densities in areas of livestock production (Newsome, 1966 and 1971). In a broad-ranging survey of African systems, Fynn et al. (2016) provide a set of criteria upon which facilitation would be expected to occur between livestock and wildlife. Most of these are predicted to result from removal of low-quality vegetation biomass and the facilitation of regrowth or increased vegetation heterogeneity. This would require significant management oversight of livestock stocking density and grazing distribution to achieve potential benefits for wildlife (see below).

There are rare examples where wildlife has been demonstrated to benefit livestock; for example, in a study across the dry and wet seasons in Kenya Odadi et al. (2011) found that, by removing stem material from grasslands, zebra facilitated grazing by cattle during the wet season (see above for competition in the same system).

As far as I am aware, there are no studies that demonstrate the direct or indirect synergistic effects between livestock and wildlife.

Overall, the literature suggests that, where positive interactions occur, there are stronger positive impacts of livestock on wildlife than vice-a-versa and little evidence of two-way interactions (Figure $2 \mathrm{~b}$ ).

\section{Effects of livestock management on wildlife}

As well as the direct and indirect interactions of herbivorous livestock and wildlife species (see above), there are effects of livestock management itself that have an effect on wildlife species. These effects can be direct and indirect, deliberate or unintended (Figure 3). The extent to which management actions impact on wildlife will, in large part, depend upon the perceptions and distribution of livestock farmers. In general, small holders are less likely to perceive wildlife as a cost to their economic and welfare outcomes, as the wildlife are

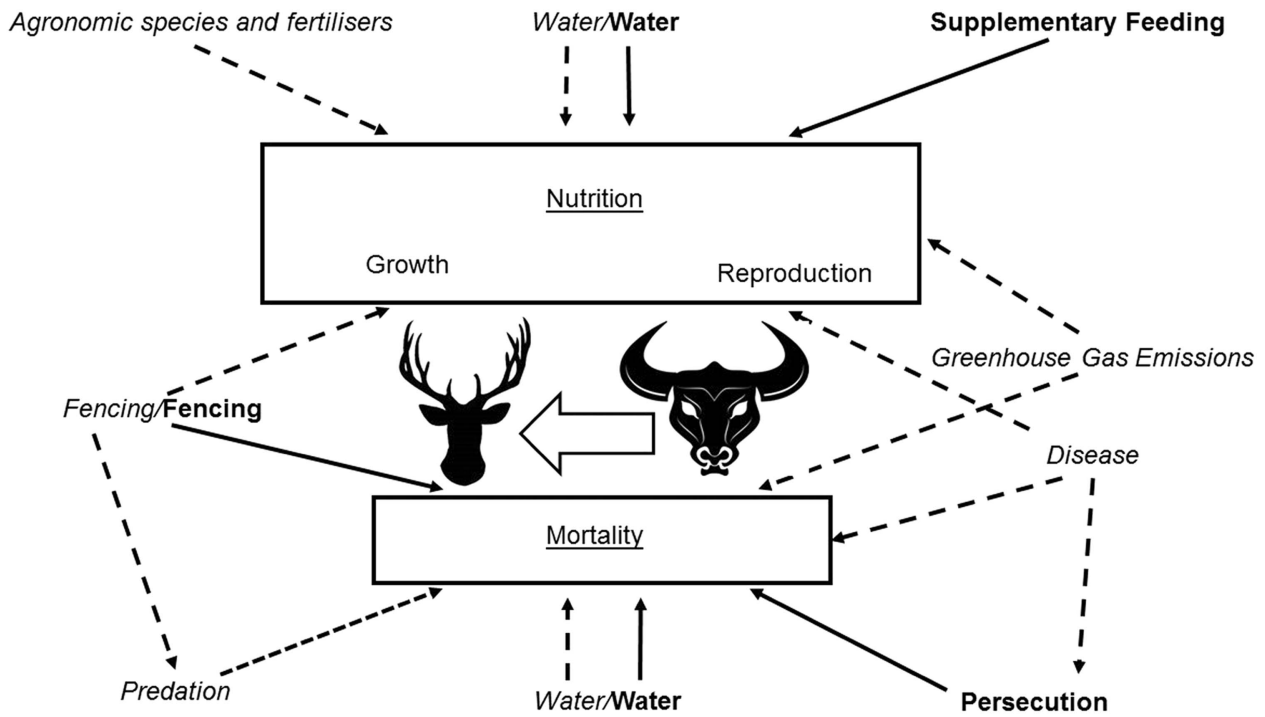

Figure 3 Direct (bold) and indirect (italics) effects of livestock management practices on the nutrition and mortality of wildlife. Arrows: $\longrightarrow=$ Direct; $-\rightarrow \rightarrow=$ indirect. Wildlife Image: http://www.pngmart.com/image/19342; Livestock image: https://www.vecteezy.com/birds-animals/22374-bull-head-vector. 
unlikely to directly affect agricultural practices and the supply of feed, unless there is competition for herbage at certain times of year, or there is the potential for wildlife to spread disease (Woodroffe et al., 2005). However, that does not mean that small holders do not impact upon wildlife. For example, Western et al. (2009) found an almost 50\% reduction in wildlife species in a semi-arid pastoral area in southern Kenya, that had been subdivided, relative to those areas which remained communal.

Generally, all farmers have the potential to be affected by the presence of wildlife on, or near, their farms. They often perceive wildlife to be a threat because of competition for fodder resources (see above) and the potential for the spread of disease from wildlife that affects livestock productivity (Knapp and Fernandez-Gimenez 2009).

\section{Direct}

Supplementary feeding. Supplementation is used to support livestock production, in both intensive and extensive systems. This supplementation can come in many forms, from hay to protein-rich pellets and mineral licks. Although supplementation is focused on livestock, wildlife can take advantage of the materials supplied. For example, red deer and white-tailed deer used salt licks put out for cattle (Schultz and Johnson, 1992; Payne et al., 2016). Several deer species have also been reported to use feed-in troughs or feeders that were targeting feed for livestock (O'Brien et al., 2006); this is causing significant concerns about the potential for the transfer of disease at these locations (Palmer et al., 2004).

Persecution. Many farmers see wildlife as a competitor for forage with livestock and/or having the potential to spread disease (du Toit, 2011). Farmers will, therefore, directly persecute wildlife by killing or poisoning those that come on their land (Dunlap 1988). Although persecution has been most common on predator species (e.g. Kolowski and Holekamp, 2006), and those herbivore species that crop raid (e.g. Naughton-Treves, 1997), there are examples of persecution of herbivorous wildlife species because of their perceived impacts on forage availability for livestock (Prins, 2000); however, the evidence for the effect of wildlife on livestock forage is slim (see above).

\section{Both indirect and direct}

Water. In arid, semi-arid and seasonally dry parts of the world, farmers often supply artificial water to support livestock. The effect of supplementary water can have both a direct and indirect effect on wildlife. For example, these artificial water points can also support wildlife positively or negatively (see above). For example, in France wild boar, Sus scrofa, were frequent visitors to artificial water points during the summer (Payne et al., 2016), as are red deer in Spain (Carrasco-Garcia et al., 2016). In central Australia, during the 1880s, the common wallaroo population expanded significantly with the introduction of water points to support the sheep industry and benefited from changes in vegetation composition associated with heavy grazing by sheep (Newsome, 1971).
Fencing. Fencing has both a direct and indirect effects on wildlife. Land ownership is one of the fundamentals for most intensive and extensive farmers. In Africa, any areas of pastoral land have recently been subdivided (Western et al., 2009) allowing farmers to invest in the infrastructure and land 'improvements' that will benefit their enterprise of livestock production. One key component of infrastructure is fencing as this keeps livestock within the boundaries of the farm. As well as keeping livestock in, fencing can also keep certain species of wildlife out of the property. This reduces competition for herbage and the potential for the spread of a disease that may be resident in the wildlife population. The normal wire fencing that is put in place for domestic livestock deters not all species of wildlife, however, many are impacted (Gordon, 2009; Rey et al., 2012).

Fencing can also be established at a much larger scale than the farm. For example, in Australia, the 'dingo' fence $(5614 \mathrm{~km})$ was constructed in the $1880 \mathrm{~s}$ to keep dingoes from predating sheep in southern Queensland, New South Wales, South Australia and Victoria. The dingo fence is only one of many barrier fences that have been constructed in Australia to reduce the impact of wildlife on livestock. These barrier fences have been shown to be major disruptors of the movement of wildlife species such as emu, Dromaius novaehollandiae (Bradby et al., 2014). There have been perverse outcomes of the fence, for example, the reduction in dingo density on the eastern side of the dingo fence has led to increases in the populations of kangaroos, Macropus spp., and rabbits, Oryctolagus cuniculus (Pople et al., 2000), that compete with sheep and cattle for herbage (Newsome, 1971). Major culling operations are now in place to try to reduce the kangaroo populations. In some areas, the reduction in dingo density has led to an increase in 'mesopredators', for example foxes and cats, which reduce rodent and rabbit densities. This leads to shrub encroachment which, again competes with grasses and reduce forage for sheep and cattle (Gordon et al., 2017). In Botswana, as a requirement of the European Union to stop the spread of foot-and-mouth disease, a large number of fences were established to keep wildlife away from major beef producing areas (van Oosterzee, 2017). These fences have had a significant detrimental impact on wildlife population, particularly, migratory species (Mbaiwa and Mbaiwa, 2006).

\section{Indirect}

Agronomic species and fertilisers. In intensive livestock systems land is cultivated and fertilisers are added to improve the nutritional value and quantity of forage on offer to livestock. These management activities generally improve the grass type of herbage on offer but can involve the addition of legumes to improve the nitrogen content of the forage. The expectation is that these 'pasture improvements' would favour wildlife species with grazer or mixed feeder dietary profiles as compared with browsers. Many species of wildlife use agronomic pastures, at least for part of the year (Putman and Moore, 1998), however, the roles that these play in the performance of wildlife populations is, generally, not known. 
Disease. As domesticated livestock species are descended from species that are close relatives of wildlife species alive today, there are many diseases they have in common. Disease is probably still one of the major issues that will impact the interaction between livestock and wildlife across the globe (Hudson et al., 2002; Woodroffe et al., 2005). Although most livestock production includes significant interventions to reduce the impact of disease on animal growth and reproduction, wildlife can still act as reservoirs of those diseases (Bengis et al., 2002), for example, Trypanosomyiasis is spread between wildlife and livestock by the tsetse fly (Glossina spp.) and the disease has constrained the opportunities for livestock production in certain areas of Africa (Alsan, 2015). Dramatic measures have been, and are, taken to reduce the contact between livestock and wildlife (e.g. persecution, fencing (see above)) or to reduce the chances of infection if contact occurs (e.g. vaccination). As well as the cases outlined above, in the Kruger National Park, African buffalo, Syncerus cafer, are managed to reduce the likelihood of them transferring the foot-and-mouth disease to cattle on farms that border the Park (Caron et al., 2003). In Yellowstone National Park, USA, the highly endangered plains bison, Bison bison, which was on the verge of extinction because of hunting pressure, is persecuted outside the Park because of fears that it will spread brucellosis (Keiter 1997, Morris and McBeth, 2003; see also Alpine ibex in Europe, Hars et al., 2013).

Some have questioned whether wildlife is actually such a risk to livestock, however, because of the perceived risks this is still the main reason for the persecution of wildlife by governments and farmers (Kock, 2005).

Predator control. Since the start of humans raising livestock, predators have been a major threat to livestock production in many parts of the world (Woodroffe and Redpath, 2015). This has led to livestock farmers persecuting predators, which, in turn, has reduced depredation on wildlife prey species (see dingo fence above). In recent years, persecution of predators in the USA and Europe has been associated with increases in deer and other wildlife species density and distribution (Ward, 2005; Harrington and Conover, 2007). On the savannas of East Africa, Bhola et al. (2012) found that the grazing by livestock on ranches produced shorter grass sward which was likely to reduce the predation risk for young warthog, Phacochoerus africanus, and topi, Damaliscus korrigum, relative to that on reserves.

Greenhouse gas emissions. A longer-term impact of livestock production on wildlife will be greenhouse gas emissions. Land use change associated with the conversion of native pasture, and deforestation during the expansion of livestock production, results in greenhouse gas emissions (Gerber et al., 2013). Livestock production itself (enteric fermentation and manure) contributes about $20 \%$ of total greenhouse gas emissions annually (U.S. Environmental Protection Agency, 2006) and the quantity emitted grows year-on-year as livestock production increases (note that the emissions from livestock are in the region of four to 50 times higher than those from wild ruminant species (Pérez-Barbería, 2017)).

These emissions contribute to climate change, which in turn can have positive or negative effects on wildlife distribution and populations (Glick et al., 2011; Fullman et al., 2017). On the positive side, the rapid expansion of white-tailed deer into boreal forests in North America is primarily attributed to climate change (Dawe and Boutin, 2016); interestingly, their expansion affects predator distributions (Latham et al., 2011; with knock on effects on livestock) and also the potential for zoonotic disease transfer to humans (Kilpatrick et al., 2014). On the negative side, unusually high humidity and temperatures have been associated with the hemorrhagic septicemia caused mass mortality of Saiga antelope, Saiga tatarica tatarica, in Kazakhstan in 2015 (Kock et al., 2018); this demonstrates the potential for the interaction between different indirect effects of livestock production on wildlife.

\section{Implications for future management of livestock and wildlife}

From the evidence provided above, the future for wildlife may appear bleak (Figure 3). There are currently three narratives about the ways in which agricultural production and nature conservation can be resolved at the landscape scale. The first has been called the 'fortress conservation', or 'land sparing', approach where biodiversity is protected within areas that exclude agricultural production and usually people (Adams, 2004; Phalan et al., 2011). Agriculture takes place outside protected areas and needs to be intensified to meet the growing demand for food. Second, the 'land sharing' approach advocates the integration of agriculture and biodiversity, mainly where, 'wildlife-friendly' farming supports biodiversity whilst at the same time meet demands for agricultural products. Finally, the 'win-win' approach sees biodiversity as providing ecosystem services (e.g. pollination and pest control) to agricultural and agriculture supports biodiversity outcomes (Gordon et al., 2017). Although these are seen as alternative approaches, in effect, they can occur in different parts of the landscape. Gordon et al. (2017) highlight the pros and cons of each approach to support wildlife. Below, I will focus on the land sharing and win-win approaches but first, a comment on food production to meet the growing demand for livestock products.

Past evidence demonstrates that most wildlife is extirpated in areas of agricultural expansion (see above). Therefore, an imperative for the future for wildlife is to limit the expansion on land that comes under agricultural production. There are three key areas of agricultural activity and the food supply chain that need to be addressed in order to limit the likely future impact of livestock production on wildlife. All of these focus on reducing or at worst halting the increase, of the land under livestock (and more broadly, agricultural production) to support the demand for livestock products from a growing, wealthier human population. First, intensification of livestock production (more product from the same 
land area) needs to occur, where it already exists, (Thornton, 2010; Alkemade et al., 2013). There are, however, risks associated with the intensification approach as the areas of high livestock productivity can draw in more people, thereby, increasing the demand for land (e.g. Vale, 2014 for the Amazon). Second, a need to reduce the waste of agricultural and food products across the whole supply chain, from farm to waste bin; at present about 30\% to $50 \%$ of food produced is wasted (Gustavsson et al., 2011). Finally, the potential of reducing demand that changed eating habits of those in developed countries and/or diverting the growth of demand for meat products in developing countries into more efficient producers of protein than herbivorous livestock (e.g. aquaculture, see Food and Agriculture Organisation, 2014).

As described above, in many extensive livestock systems, where livestock relies on native vegetation for their food supply, inputs (e.g. supplementary feed) and infrastructure (water points) lead to heavy grazing pressure and homogenisation and degradation of the ecosystem. Ultimately, this will have negative consequences, not only for wildlife but also, for livestock production itself. Lighter stocking rates of domestic livestock tend to create great heterogeneity in vegetation structure over small to large spatial scales driving vegetation dynamics, biodiversity and potentially also improving wildlife habitats (Dumont et al., 2012; Ren et al., 2015). Therefore, farmers should be looking to ways of reducing stocking rates and implementing management strategies that both maintain the economic return from livestock (and potentially wildlife) enterprise as well as maintaining vegetation productivity. There is evidence, from, for example, Australia, that reducing stocking densities in extensive systems can improve vegetation condition, thereby improving individual animal performance, reducing the need for inputs, for example supplementation of food, and increase the economic return and sustainability of the enterprise (Gordon and Nelson, 2007). In Europe, adopting rotational grazing management regimes appears to be able to maintain livestock productivity (generally at less intense grazing pressures) (e.g. Farruggia et al., 2012; Ravetto Enri et al., 2017). These reduced stocking rates will result in increased vegetation heterogeneity, providing opportunities for exploitation by a range of wildlife species, and may even be beneficial to livestock production (win-win outcomes; see also Gordon et al., 2017).

If we look at areas of the landscape which focus on wildlife management (conservation, hunting) purposes, livestock are often used to create heterogeneity in the landscape with benefits for wildlife that occupy a range of niches (Gordon and Duncan, 1988; Fuhlendorf and Engle, 2001; Krausman et al., 2009). This is generally achieved through low to moderate stocking rates of livestock or rotational grazing where areas are rested from grazing for periods (Krausman et al., 2009). Although the impacts on livestock production are not usually measured, as indicated above, this can lead to improved livestock production (Gordon and Nelson, 2007) as well as benefiting the populations of wildlife.

Although history suggests that wildlife suffers where livestock production dominates, there are potential benefits to integrating livestock and wildlife, particularly in extensive livestock production systems. A combination of wildlife and livestock populations increases ecosystem resilience in the face of climate change and the threats from invasive species (Otieno and Muchapondwa 2016; du Toit et al., 2017). For this approach to work there have to be economic benefits to farmers from maintaining wildlife on their land, which need to outweigh the benefits of increasing livestock stocking rates. There are a number of options that would promote conservation on land owned for livestock production, for example, conservation easements and leases, payments for ecosystem services, wildlife tourism, game ranching and hunting (Woodroffe et al., 2005; Gitahi and Fitzgerald, 2011). As yet, there is a great deal of narrative about this approach from wildlife biologists (see du Toit et al., 2017), however, there are only rare instances demonstrating the benefits of the comanagement of wildlife and livestock (Otieno and Muchapondwa, 2016). Much more research into the potential and threats from co-management of wildlife and livestock is needed across the continents and the ecosystems on the planet.

\section{Future research}

\section{Improve efficiency of livestock production}

My starting point is a call for animal scientists to improve the efficiency of livestock production on land that is already under livestock production. This includes improving the use of all of the inputs into the enterprise, reducing the externalities of those inputs and increasing animal production, from growth through to disease management. These advances will limit the need for increasing the land area under livestock production to meet current and future needs for livestock products.

\section{Co-management of livestock and wildlife}

Although livestock-wildlife interactions have been the subject of a multitude of studies over the years; there is still a lot that is not understood. The nature of the potential link between livestock or wildlife feeding behaviour on vegetation quantity, composition, structure and quality and the consequential effects on other species of interest requires further experimental research. The majority of the evidence, to date, on livestock-wildlife interactions is observational; an experimental approach (e.g. Hester et al., 1999) is needed to truly test the hypotheses about whether the interactions are neutral, negative or positive. Only through these experimental tests will the research field truly move away from observation of pattern to understanding the mechanisms underlying the interaction (e.g. why do many wildlife species avoid livestock even when humans are not present). Also, there is the matter of scale, both in space and in demographics and production. Very few studies test the benefits of co-grazing at the landscape scale (Bhola et al., 2012); even fewer look at the potential performance improvements in livestock and wildlife (Gordon, 1988; Odadi et al., 2011).

More broadly, research is needed to provide guidance for ways in which livestock production can go hand-in-hand 
with wildlife management (e.g. conservation, economic benefits; Gordon et al., 2004), within a socio-ecological systems context. This will include research on changing the long-held perception of many farmers that wildlife is a threat to their enterprise and livelihoods (Hulme and Murphree, 2001; Knapp and Fernandez-Gimenez, 2009; du Toit, 2011). As stated above, there is extensive research on the ways in which wildlife can be integrated into livestock enterprises, particularly for eco-tourism enterprises (du Toit et al., 2017). Much of this comes from wildlife biologists and sociologists; there is a requirement for more engagement, and potentially research, from the livestock and veterinary sciences part of the system. The potential for the incorporation of wildlife products (meat and hides) into supply chains in middle- and high-income countries requires further research (particularly market research) and policy development. In my country of residence, Australia, the local supermarkets sell kangaroo meat as low cholesterol, green, organic product (Spiegel and Wynn, 2014); the same happens with deer venison in Europe (Hoffman and Wiklund, 2006). Meat, derived from wildlife species could form a valuable resource to support the growing demand for meat across the globe (Cawthorn and Hoffman, 2014). Much more research is needed on product and supply chain development and public attitudes towards no-traditional foods if this potential is to be realised.

As stated above, the disease is still one of the major issues affecting the potential for co-management of wildlife and livestock in many parts of the world. It not only dominates the interactions between wildlife and livestock, directly and indirectly but also drives the perceptions of wildlife by many farmers (de Garine-Wichatitsky et al., 2013). Although much is known about the diseases themselves management and government policy needs to be more nuanced if the positive benefits of wildlife on farms is to be realised; for example, managing disease in the wildlife population may reduce the need for disease interventions in livestock (Silk et al., 2017). This is a key area for future research in wildlife/livestock interaction (Miller et al., 2013).

A truly socio-ecological systems approach to livestockwildlife interactions and achieving win-win outcomes will require biophysical (e.g. ecologists, animal and veterinary scientists and agronomists) to work with the social and economic scientists. With the growing demand for livestock products, the future of wildlife depends upon a transdisciplinary approach to provide practical solutions for livestock farmers, wildlife managers and policy makers. The planet's unique wildlife biodiversity needs our help, and quickly.

\section{Acknowledgements}

First, the author would like to thank the organisers of the International Symposium on the Nutrition of Herbivores 2018 for inviting me to present a plenary paper in the session on 'Wild Herbivores'. The research, and ideas, presented in this review were developed whilst the author was employed at the Macaulay Land Use Research Institute, CSIRO, the James Hutton Institute and James Cook University. The author thanks Yvette Williams and two anonymous reviewers for their comments on an earlier version of this manuscript. The author would, however, state that the views presented in this paper are entirely on his own.

\section{Declaration of interest}

The authors declare no conflicts of interest.

\section{Ethics statement}

This review did require any requirement for animal or human ethics.

\section{Software and data repository resources}

No primary data was collected to support this review.

\section{References}

Acevedo P, Farfán MÁ, Márquez AL, Delibes-Mateos M, Real R and Vargas JM 2011. Past, present and future of wild ungulates in relation to changes in land use. Landscape Ecology 26, 19-31.

Adams WM 2004. Against extinction: the story of conservation. Earthscan, London, UK.

Alexandratos N and Bruinsma J 2012. World agriculture towards 2030/2050: the 2012 revision. ESA Working paper No. 12-03, Food and Agriculture Organization, Rome, Italy.

Alkemade R, Reid RS, van den Berg M, de Leeuw J and Jeuken M 2013. Assessing the impacts of livestock production on biodiversity in rangeland ecosystems. Proceedings of the National Academy of Sciences 110, 20900-20905.

Alsan M 2015. The effect of the tsetse fly on African development. American Economic Review 105, 382-410.

Bengis RG, Kock RA and Fischer J. 2002. Infectious animal diseases: the wildlife/ livestock interface. Revue Scientifique et Technique-Office International des Epizooties 21, 53-66.

Bhola N, Ogutu JO, Piepho HP, Said MY, Reid RS, Hobbs NT and Olff H 2012. Comparative changes in density and demography of large herbivores in the Masai Mara Reserve and its surrounding human-dominated pastoral ranches in Kenya. Biodiversity and Conservation 21, 1509-1530.

Biggs R, Schlüter M and Schoon ML 2015. Principles for building resilience: sustaining ecosystem services in social-ecological systems. Cambridge University Press, Cambridge, UK.

Boone RB, BurnSilver SB, Thornton PK, Worden JS and Galvin KA 2005. Quantifying declines in livestock due to land subdivision. Rangeland Ecological Management 58, 523-532.

Bradby K, Fitzsimons JA, Del Marco A, Driscoll DA, Ritchie EG, Lau J, Bradshaw $\mathrm{CJ}$ and Hobbs RJ 2014. Ecological connectivity or Barrier Fence? Critical choices on the agricultural margins of Western Australia. Ecological Management \& Restoration 15, 180-190.

Bruinsma J (Ed.) 2003. World agriculture: towards 2015/2030. An FAO perspective. Food and Agriculture Organization/Earthscan Publications, Rome, Italy/ London, UK.

Caron A, Cross PC and Du Toit JT 2003. Ecological implications of bovine tuberculosis in African buffalo herds. Ecological Applications 13, 1338-1345.

Carrasco-Garcia R, Barasona JA, Gortazar C, Montoro V, Sanchez-Vizcaino JM and Vicente $J$ 2016. Wildlife and livestock use of extensive farm resources in South Central Spain: implications for disease transmission. European Journal of Wildlife Research 62, 65-78.

Cawthorn DM and Hoffman LC 2014. The role of traditional and non-traditional meat animals in feeding a growing and evolving world. Animal Frontiers 4, 6-12. Dawe KL and Boutin S 2016. Climate change is the primary driver of white-tailed deer (Odocoileus virginianus) range expansion at the northern extent of its range; land use is secondary. Ecology and Evolution 6, 6435-6451.

de Garine-Wichatitsky M, Miguel E, Mukamuri B, Garine-Wichatitsky E, Wencelius J, Pfukenyi DM and Caron A 2013. Coexisting with wildlife in transfrontier conservation areas in Zimbabwe: Cattle owners' awareness of disease risks and perceptions of the role played by wildlife. Comparative Immunology, Microbiology and Infectious Diseases 36, 321-332. 
de Leeuw J, Waweru MN, Okello 00, Maloba M, Nguru P, Said MY, Aligula HM, Heitkönig IM and Reid RS 2001. Distribution and diversity of wildlife in northern Kenya in relation to livestock and permanent water points. Biological Conservation 100, 297-306.

Delgado C, Rosegrant M, Steinfeld H, Ehui S and Courbois C 1999. Livestock to 2020: the next food revolution. International Food Policy Research Institute, Washington, DC, USA.

Dumont $B$, Rossignol N, Loucougaray $G$, Carrère $P$, Chadoeuf J, Fleurance $G$, Bonis A, Farruggia A, Gaucherand S, Ginane $C$ and Louault F 2012. When does grazing generate stable vegetation patterns in temperate pastures? Agriculture, Ecosystems \& Environment 53, 50-56.

Dunlap TR 1988. Saving America's wildlife: ecology and the American mind, 1850-1990. Princeton University Press, Princeton, NJ, USA.

du Toit JT 2011. Coexisting with cattle. Science 333, 1710-1711.

du Toit JT and Cumming DHM 1999. Functional significance of ungulate diversity in African savannas and the ecological implications of the spread of pastoralism. Biodiversity and Conservation 8, 1643-1661.

Du Toit JT and Olff H 2014. Generalities in grazing and browsing ecology: using across-guild comparisons to control contingencies. Oecologia 174, 10751083.

du Toit JT, Cross PC and Valeix M 2017. Managing the livestock-wildlife interface on rangelands. In. Rangeland Systems), ed. DD Briske), pp. 395-425. Springer International Publishing, New York, USA.

Edwards GP, Croft DB and Dawson TJ 1996. Competition between red kangaroos (Macropus rufus) and sheep (Ovis aries) in the arid rangelands of Australia. Australian Journal of Ecology 21, 165-172.

Farruggia A, Dumont B, Scohier A, Leroy T, Pradel P and Garel JP 2012. An alternative rotational stocking management designed to favour butterflies in permanent grasslands. Grass and Forage Science 67, 136-149.

Food and Agriculture Organisation 2014. The state of world fisheries and aquaculture: opportunities and challenges. FAO, Rome, Italy.

Foley JA, DeFries R, Asner GP, Barford C, Bonan G, Carpenter SR, Chapin FS, Coe MT, Daily GC, Gibbs HK and Helkowski JH 2005. Global consequences of land use. Science 309, 570-574.

Frisina MR and Keigley RB 2004. Habitat changes: mount Haggin Wildlife Management Area. Rangelands 26, 3-13.

Franklin WL, Powell KJ and Youngs CR 1994. Guard Llamas. Department of Animal Ecology, College of Agriculture, lowa State University, Ames, USA.

Fritz H, De Garine-Wichatitsky M and Letessier G 1996. Habitat use by sympatric wild and domestic herbivores in an African savanna woodland: the influence of cattle spatial behaviour. Journal of Applied Ecology 33, 589-598.

Fuhlendorf SD and Engle DM 2001. Restoring heterogeneity and rangelands: ecosystem management based on evolutionary grazing patterns. BioScience 51 625-632.

Fullman TJ, Bunting EL, Kiker GA and Southworth J. 2017. Predicting shifts in large herbivore distributions under climate change and management using a spatially-explicit ecosystem model. Ecological Modelling 352, 1-8.

Fynn RWS, Augustine DJ, Peel MJS and de Garine-Wichatitsky M 2016. Strategic management of livestock to improve biodiversity conservation in African savannahs: a conceptual basis for wildlife-livestock coexistence. Journal of Applied Ecology 53, 388-397.

Gerber PJ, Steinfeld H, Henderson B, Mottet A, Opio C, Dijkman J, Falcucci A and Tempio $G$ 2013. Tackling climate change through livestock: a global assessment of emissions and mitigation opportunities. Food and Agriculture Organization of the United Nations, Rome, Italy.

Gitahi N and Fitzgerald KH 2011. Conserving wildlife on private lands: the legal framework for landownership and new tools for land conservation. In Conserving wildlife in African landscapes: Kenya's Ewasoecosystem (ed. NJ Georgiadis), pp. 95-103. Smithsonian contributions to zoology 632. Smithsonian Institution Scholarly Press, Washington, DC, USA.

Glick P, Stein BA and Edelson NA 2011. Scanning the conservation horizon: a guide to climate change vulnerability assessment. National Wildlife Federation, Washington, DC, USA.

Gordon CE, Eldridge DJ, Ripple WJ, Crowther MS, Moore BD and Letnic M 2017. Shrub encroachment is linked to extirpation of an apex predator. Journal of Animal Ecology 86, 147-157.

Gordon IJ 1988. Facilitation of red deer grazing by cattle and its impact on red deer performance. Journal of Applied Ecology 25, 1-10.
Gordon IJ 2009. What is the future for wild, large herbivores in human-modified landscapes? Wildlife Biology 15, 1-9.

Gordon IJ and Duncan P 1988. Pastures new for conservation. New Scientist 1604, 54-59.

Gordon IJ, Hester AJ and Festa-Bianchet M. 2004. The management of wild large herbivores to meet economic, conservation and environmental objectives. Journal of Applied Ecology 41, 1021-1031.

Gordon IJ and Illius AW 1989. Resource partitioning by ungulates on the Isle of Rhum. Oecologia 79, 383-389.

Gordon IJ and Nelson B 2007. Reef safe beef: environmentally sensitive livestock management for the grazing lands of the Great Barrier Reef catchments. In Redesigning animal agriculture; the challenge of the 21st century (ed. DL Swain, E Charmley, JW Steel and SG Coffey), pp. 171-184. CABI Publishing, Wallingford, UK.

Gordon IJ, Squire GR and Prins HHT 2017. Conclusion: re-engaging agriculture with nature. In Food production and nature conservation: conflicts and solutions (eds. Gordon, IJ, Prins, HHT and Squire, GR), pp. 332-342. Earthscan Food and Agriculture. Routledge, London, UK.

Gustavsson J, Cederberg C, Sonesson U, van Otterdijk R and Meybeck A 2011. Global Food Losses and Food Waste Section 3.2. Food and Agriculture Organisation of the United Nations, Rural Infrastructure and Agro-Industries Division, Rome, Italy.

Harrington JL and Conover MR 2007. Does removing coyotes for livestock protection benefit free-ranging ungulates? Journal of Wildlife Management 71, 1555-1560.

Hars J, Rautureau S, Jaÿ M, Game Y, Gauthier D and Herbaux J-P 2013. Un foyer de brucellose chez les ongulés sauvages du massif du Bargy en Haute-Savoie. Bulletin Epidemiologique Sante animale Alimentation 60, 2-6.

Hempson GP, Archibald S and Bond WJ 2015. A continent-wide assessment of the form and intensity of large mammal herbivory in Africa. Science 350, 1056-1061. Herfindal I, Lande US, Solberg EJ, Rolandsen CM, Roer 0 and Wam HK 2017. Weather affects temporal niche partitioning between moose and livestock. Wildlife Biology 18, wlb-00275.

Hester AJ, Gordon IJ, Baillie GJ and Tappin E 1999. Foraging behaviour of sheep and red deer within natural heather/grass mosaics. Journal of Applied Ecology $36,133-146$

Hoffman LC and Wiklund E 2006. Game and venison-meat for the modern consumer. Meat Science 74, 197-208.

Hudson PJ, Rizzoli A, Grenfell BT, Heesterbeek H and Dobson AP 2002. The Ecology of Wildlife Disease. Oxford University Press, Oxford, UK.

Hulme D and Murphree M 2001. African wildlife and livelihoods. the promise and performance of community conservation. James Curry Ltd, Oxford, UK.

Illius AW and Gordon IJ 1987. The allometry of food intake in grazing ruminants. Journal of Animal Ecology 56, 989-999.

Izquierdo AE and Grau HR 2009. Agriculture adjustment, land-use transition and protected areas in Northwestern Argentina. Journal of Environmental Management 90, 858-865.

Keiter RB 1997. Greater Yellowstone's bison: unraveling of an early American wildlife conservation achievement. Journal of Wildlife Management 61, 1-11.

Khadka K and James DA 2016. Habitat selection by endangered Himalayan musk deer (Moschus chrysogaster) and impacts of livestock grazing in Nepal Himalaya: Implications for conservation. Journal for Nature Conservation 31, 38-42.

Kilpatrick HJ, Labonte AM and Stafford KC III 2014. The relationship between deer density, tick abundance, and human cases of Lyme disease in a residentia community. Journal of Medical Entomology 51, 777-784.

Kock RA 2005. What is this infamous 'wildlife/livestock disease interface?' A review of current knowledge for the African continent. In Conservation and development interventions at the wildlife/livestock interface - Implications for wildlife, livestock and human health (ed. SA Osofsky), pp. 1-13. International Union for the Conservation of Nature, Gland, Switzerland.

Kock RA, Orynbayev M, Robinson S, Zuther S, Singh NJ, Beauvais W, Morgan ER, Kerimbayev A, Khomenko S, Martineau HM and Rystaeva R 2018. Saigas on the brink: Multidisciplinary analysis of the factors influencing mass mortality events. Science Advances 4, eaao2314

Knapp CN and Fernandez-Gimenez ME 2009. Knowledge in practice: documenting rancher local knowledge in northwest Colorado. Rangeland Ecology and Management 62, 500-509.

Kolowski JM and Holekamp KE 2006. Spatial, temporal, and physical characteristics of livestock depredations by large carnivores along a Kenyan reserve border. Biological conservation 128, 529-541. 
Krausman PR, Naugle DE, Frisina MR, Northrup R, Bleich VC, Block WM, Wallace MC and Wright JD 2009. Livestock grazing, wildlife habitat, and rangeland values. Rangelands 31, 15-19.

Latham ADM, Latham MC, McCutchen NA and Boutin S 2011. Invading whitetailed deer change wolf-caribou dynamics in Northeastern Alberta. Journal of Wildlife Management 75, 204-212.

Mbaiwa JE and Mbaiwa OI 2006. The effects of veterinary fences on wildlife populations in Okavango Delta, Botswana. International Journal of Wliderness 12, 17-41.

McLeod R 2004. Counting the Cost: Impact of Invasive Animals in Australia 2004. Cooperative Research Centre for Pest Animal Control, Canberra, Australia. Merrill LB, Teer J and Wallmo OC 1957. Reaction of deer populations to grazing practices. Texas Agriculture Program 3, 10-12.

Miller RS, Farnsworth ML and Malmberg JL 2013. Diseases at the livestockwildlife interface: status, challenges, and opportunities in the United States. Preventive Veterinary Medicine 110, 119-132.

Mishra C, van Wieren SE, Ketner P, Heitkönig IMA and Prins HHT 2004. Competition between domestic livestock and wild bharal Pseudois nayaur in the Indian Trans-Himalaya. Journal of Applied Ecology 41, 344-354.

Morris JM and McBeth MK 2003. The New West in the context of extractive commodity theory: the case of bison-brucellosis in Yellowstone National Park. The Social Science Journal 40, 233-247.

Newby J 2014. Home, home on the range.... Oryx 48, 157.

Newsome AE 1966. The influence of food on breeding in the red kangaroo in central Australia. CSIRO Wildlife Research 11, 187-196.

Newsome AE 1971. Competition between wildlife and domestic livestock. Australian Veterinary Journal 47, 577-586.

Naughton-Treves $L$ 1997. Farming the forest edge: vulnerable places and people around Kibale National Park, Uganda. Geographical Review 87, 27-46.

O'Brien DJ, Schmitt SM, Fitzgerald SD, Berry DE and Hickling GJ 2006. Managing the wildlife reservoir of Mycobacterium bovis: the Michigan, USA, experience. Veterinary Microbiology 112, 313-323.

Odadi WO, Karachi MK, Abdulrazak SA and Young TP 2011. African wild ungulates compete with or facilitate cattle depending on season. Science 333, 1753-1755.

Ogutu JO, Piepho H-P, Reid RS, Rainy ME, Kruska RL, Worden JS, Meshack Nyabenge M and Hobbs NT 2010. Large herbivore responses to water and settlements in savannas. Ecological Monographs 80, 241-266.

Otieno J and Muchapondwa E 2016. Agriculture and adaptation to climate change: the role of wildlife ranching in South Africa. Economic Research Southern Africa Working Paper No. 579, National Treasury, Pretoria, South Africa.

Palmer MV, Waters WR and Whipple DL 2004. Investigation of the transmission of Mycobacterium bovis from deer to cattle through indirect contact. American Journal of Veterinary Research 65, 1483-1489.

Payne A, Chappa S, Hars J, Dufour B and Gilot-Fromont E 2016. Wildlife visits to farm facilities assessed by camera traps in a bovine tuberculosis-infected area in France. European Journal of Wildlife Research 62, 33-42.

Pérez-Barbería FJ 2017. Scaling methane emissions in ruminants and global estimates in wild populations. Science of the Total Environment 579 , 1572-1580

Phalan B, Onial M, Balmford A and Green RE 2011. Reconciling food production and biodiversity conservation: land sharing and land sparing compared. Science 333, 1289-1291.

Pople AR and McLeod SR 2000. Kangaroo management and the sustainable use of rangelands. In Management for sustainable ecosystems (ed. Hale PT, Petrie A, Moloney D and Sattler P), pp. 78-86. Centre for Conservation Biology, The University of Queensland, Brisbane, Australia.

Pople AR, Grigg GC, Cairns SC, Beard LA and Alexander P 2000. Trends in the numbers of red kangaroos and emus on either side of the South Australian dingo fence: evidence for predator regulation? Wildlife Research 27, 269-276.

Prins HHT 2000. Competition between wildlife and livestock in Africa. In Wildlife conservation by sustainable use (ed. Prins, HHT, Grootenhuis JG and Dolan TT) pp. 51-80. Springer, Netherlands.

Putman RJ and Moore NP 1998. Impact of deer in lowland Britain on agriculture, forestry and conservation habitats. Mammal Review 28, 141-164.

Ravetto Enri SR, Probo M, Farruggia A, Lanore L, Blanchetete A and Dumont B 2017. A biodiversity-friendly rotational grazing system enhancing flower-visiting insect assemblages while maintaining animal and grassland productivity. Agriculture, Ecosystems \& Environment 241, 1-10.

Ren H, Han G, Ohm M, Schönbach P, Gierus M and Taube F 2015. Do sheep grazing patterns affect ecosystem functioning in steppe grassland ecosystems in Inner Mongolia? Agriculture, Ecosystems \& Environment 25, 213, 1-10.

Rey A, Novaro AJ and Guichón ML 2012. Guanaco (Lama guanicoe) mortality by entanglement in wire fences. Journal for Nature Conservation 20, 280-283.

Robinson TP, Wint GW, Conchedda G, Van Boeckel TP, Ercoli V, Palamara E, Cinardi G, D'Aietti L, Hay SI and Gilbert M 2014. Mapping the global distribution of livestock. PloS one 9, e96084.

Schieltz JM and Rubenstein DI 2016. Evidence based review: positive versus negative effects of livestock grazing on wildlife. What do we really know? Environmental Research Letters 11, 113003.

Schroeder NM, Ovejero R, Moreno PG, Gregorio P, Taraborelli P, Matteucci SD and Carmanchahi PD 2013. Including species interactions in resource selection of guanacos and livestock in Northern Patagonia. Journal of Zoology 291, 213-225. Schultz SR and Johnson MK 1992. Effects of supplemental mineral licks on white-tailed deer. Wildlife Society Bulletin 20, 303-308.

Silk MJ, Croft DP, Delahay RJ, Hodgson DJ, Boots M, Weber N and McDonald RA 2017. Using social network measures in wildlife disease ecology, epidemiology, and management. BioScience 67, 245-257.

Smit IP, Grant CC and Devereux BJ 2007. Do artificial waterholes influence the way herbivores use the landscape? Herbivore distribution patterns around rivers and artificial surface water sources in a large African savanna park. Biological Conservation 136, 85-99.

Spiegel NB and Wynn PC 2014. Promoting kangaroo as a sustainable option for meat production on the rangelands of Australia. Animal Frontiers 4, 38-45.

Stewart KM, Bowyer RT, Kie JG, Cimon NJ and Johnson BK 2002. Temporospatial distributions of elk, mule deer, and cattle: resource partitioning and competitive displacement. Journal of Mammalogy 83, 229-244.

Thornton PK 2010. Livestock production: recent trends, future prospects. Philosophical Transactions of the Royal Society of London B: Biological Sciences 365, 2853-2867.

Traba J, Iranzo EC, Carmona CP and Malo JE 2017. Realised niche changes in a native herbivore assemblage associated with the presence of livestock. Oikos $126,1400-1409$.

United Nations 2017. World population prospects: the 2017 revision. Population Division, Population Estimates and Projections Section, United Nations Department of Economic and Social Affairs, New York, NY, USA. Retrieved on 26 December 2017. http://esa.un.org/unpd/wpp/index.htm.

U.S. Environmental Protection Agency 2006. Global anthropogenic non-CO2 greenhouse gas emissions, 1990-2020. EPA Report 430-R-06-003. U.S. Environmental Protection Agency, Washington, DC, USA.

Vale PM 2014. The conservation versus production trade-off: does livestock intensification increase deforestation? Evidence from the Brazilian Amazon. Working Paper, No. 20.2015, Fondazione Eni Enrico Mattei, Milan, Italy.

van Oosterzee P 2017. Wildlife interrupted. New Scientist 3155, 32-35.

Ward Al 2005. Expanding ranges of wild and feral deer in Great Britain. Mammal Review 35, 165-173.

Western D 1989. Conservation without parks: wildlife within the rural landscape. In Conservation for the 21st century (ed. D Western and M Pearl), pp. 158-165. Oxford University Press, New York, NY, USA.

Western D, Groom R and Worden J 2009. The impact of subdivision and sedentarization of pastoral lands on wildlife in an African savanna ecosystem. Biological Conservation 142, 2538-2546.

Wiens JA 1989. The ecology of bird communities. Vol. 2: processes and variations. Cambridge University Press, Cambridge, UK.

Wirsenius S, Azar C and Berndes G 2010. How much land is needed for global food production under scenarios of dietary changes and livestock productivity increases in 2030? Agricultural Systems 103, 621-638.

Woodroffe R and Redpath SM 2015. When the hunter becomes the hunted. Science 348, 1312-1314.

Woodroffe R, Thirgood SJ and Rabinowitz A 2005. People and Wildlife: Conflict or Co-existence. Wiley-Blackwell, Oxford, UK.

World Bank 2017. World bank data for low and middle income countries. Retrieved on 26 December 2017 from https://data.worldbank.org/income-level/ low-and-middle-income. 